\title{
Punkt Informacyjno-Koordynacyjny dla Osób z Niepełnosprawnością (PIKON) jako wsparcie informacyjne na rzecz poprawy jakości życia osób z niepełnosprawnościami i ich rodzin
}

\begin{abstract}
Teresa Serafin, Punkt Informacyjno-Koordynacyjny dla Osób Niepetnosprawnościa (PIKON) jako wsparcie informacyjne na rzecz poprawy jakości życia osób z niepetnosprawnościami $i$ ich rodzin [Information \& Co-ordination Point for Persons with Disabilities (PIKON) as a form of information support aimed at improving the quality of life of persons with disabilities and their families]. Interdyscyplinarne Konteksty Pedagogiki Specjalnej, nr 21, Poznań 2018. Pp. 103-123. Adam Mickiewicz University Press. ISSN 2300-391X. DOI: https:/ / doi.org/10.14746/ikps.2018.21.06

This article presents, undertaken by social organizations and the office of the Capital City of Warsaw, initiatives aimed at developing a model of cooperation between institutions performing tasks in the field of various areas of social policy. These initiatives concern, inter alia, continuing the activities of the education system in the field of equalizing the chances of students with disabilities by institutions performing tasks in the field of various areas of social policy, including those supporting professional and personal functioning of adults. One of the directions of this objective is the creation of an information and coordination point to support adults with disabilities in solving their problems, eg by providing information on possible participation in social rehabilitation and/or employment in an open, supported or protected labor market.
\end{abstract}

KEY WORDS: disability, needs, social policy, cooperation, providing support, informing about possibilities 


\section{Wstęp}

Od wielu lat w strukturze populacji społecznych zachodzą zmiany demograficzne powodujące m.in. wydłużenie przeciętnego czasu trwania życia osób oraz spadek przyrostu naturalnego, które tworzą wyzwania dla każdej z dziedzin życia społecznego. Również indywidualna i społeczna tożsamość człowieka ${ }^{1}$ ma wpływ na identyfikowanie własnej osoby, na nawiązywanie relacji, podejmowanie współpracy, akceptację i tolerancję. Teorie popularyzowane obecnie przez nauki społeczne i humanistyczne postulują traktowanie jako niepodważalnej wartości, współistnienia różnych grup społecznych na zasadzie równych praw i obowiązków. Aby im sprostać, podmioty odpowiedzialne za realizację polityki społecznej naszego $\mathrm{kraju}^{2}$ na obszarze gminy, powiatu i województwa powinny konsekwentnie realizować działania prewencyjne. Działania te mogą polegać na:

- rozpoznawaniu potrzeb mieszkańców, w tym osób z potrzebami specjalnymi, według wieku rozwojowego,

- opracowaniu spójnej długoterminowej i międzyresortowej strategii uwzględniającej uczestnictwo wszystkich grup mieszkańców w życiu społecznym (ze wskazaniem na grupy osób defaworyzowanych) i zapewnieniu koordynacji tych działań,

1 Pojęcie tożsamości występuje w kontekście dwu najważniejszych dla człowieka relacji: stosunku do siebie samego i stosunku do innych ludzi, a więc zarazem do kultury i tradycji. Wskazuje na szczególny typ związku, jaki łączy podmiot z nim samym - z jednej strony, z jego własną psychofizyczną i moralną kondycją (self identity) z drugiej zaś - na związek z innymi. Związek ten jest oparty na (mniej lub bardziej) świadomych postawach wobec siebie samego i innych ludzi, a wiec zarazem kultury i tradycji. (na podstawie książki: Psychologia osobowości. Tożsamość człowieka, red. A. Gałdowa, Wydawnictwo UJ, Kraków 2000).

2 Za realizacje polityki społecznej naszego kraju odpowiadają zarówno urzędy centralne, samorządowe - poszczególnych szczebli zarządzania (czyli jednostki samorządu terytorialnego pełniące funkcję organów prowadzących przedszkola, szkoły i placówki), jak i instytucje resortów mających wpływ na wspieranie zdrowia i rozwoju osobistego człowieka. 
- zapewnieniu wsparcia rodzinom, w których u jednego z jej członków występuje niepełnosprawność, przez asystenta rodziny ${ }^{3}$,

- tworzeniu warunków do kształcenia dzieci i młodzieży z niepełnosprawnością w szkołach zlokalizowanych najbliżej miejsca ich zamieszkania,

- kontynuowaniu systemowych i międzyresortowych, wielospecjalistycznych działań na rzecz osób z niepełnosprawnością i ich rodzin (np. przez wspieranie: rozwoju sieci mieszkań chronionych zapewniających całodobową pomoc dorosłym osobom z niepełnosprawnością oraz mieszkań terapeutycznych pozwalających na kształtowanie samodzielności tych osób w przyjaznych i dostosowanych warunkach, udzielanie pomocy rodzinie $\mathrm{w}$ zakładaniu spółdzielni socjalnych, jak również ułatwianie dostępu osobom $\mathrm{z}$ niepełnosprawnością do kształcenia ustawicznego, absolwentom szkół dla młodzieży).

W ramach działań systemowych na rzecz osób z niepełnosprawnością powinny być też zapewniane: a) ochrona zdrowia i szerokoprofilowa pomoc medyczna zgodna ze wskazaniami wynikającymi ze ich stanu zdrowia oraz finansowana tych działan z Narodowego Funduszu Zdrowia (decydującego o zakresie profilaktyki zdrowotnej, leczeniu i rehabilitacji), b) rehabilitacja społeczna oraz pomoc socjalna ich rodzinie, organizowana przez ośrodki pomocy społecznej działające w ramach resortu zabezpieczenia społecznego, c) likwidowanie barier architektonicznych oraz udostępnianie systemu usług rekompensujących ograniczenia funkcjonalne i umożliwiające dzie-

3 Uchwała Nr 160 Rady Ministrów z 20 grudnia 2016 r. w sprawie programu kompleksowego wsparcia dla rodzin "Za życiem” opublikowana została w Monitorze Polskim poz. 1250. We wstępie do założeń programowych czytamy: „Wsparcie osób niepełnosprawnych i ich rodzin stanowi priorytetowe zadanie państwa wymagające podjęcia wieloaspektowych działań. (...) Stąd też działania pomocowe państwa powinny być skierowane do całej rodziny. Niepełnosprawność wpływa na wiele obszarów życia rodziny, tj. na jej sytuację materialną, społeczną, czy też zdrowotną. Przyjęte w programie rozwiązania prawno-organizacyjne oraz finansowe mają na celu umożliwienie rzeczywistej i pełnej integracji społecznej osób niepełnosprawnych oraz wsparcie psychologiczne, społeczne, funkcjonalne i ekonomiczne ich rodzin". 
ciom, młodzieży i dorosłym osobom z niepełnosprawnością maksymalną niezależność życiową w środowisku przez Państwowy Fundusz Rehabilitacji Osób Niepełnosprawnych.

W 2016 r. Ministerstwo Rodziny, Pracy i Polityki Społecznej wprowadziło nowe przepisy, w których jednym z zadań wiodących jest udzielanie pomocy rehabilitacyjnej i wspierającej rodzinom osób z niepełnosprawnością poprzez zapewnianie im czasu na odpoczynek (tzw. opieka wytchnieniowa) oraz udzielenie pomocy, $\mathrm{w}$ przypadku zdarzenia losowego, w załatwianiu spraw codziennych lub uczestnictwa członka rodziny $w$ aktywizacji zawodowej organizowanej przez powiatowy urząd pracy, jak również podjęcie przez członka rodziny zatrudnienia $\mathrm{w}$ pełnym lub niepełnym wymiarze czasu pracy. Natomiast istotą pomocy kierowanej do osób z zaburzeniami psychicznymi, ze spektrum autyzmu i z niepełnosprawnościami sprzężonymi jest, między innymi, rozszerzenie dostępu do instytucjonalnych form pomocy większej grupie osób i rozwój sieci środowiskowych domów samopomocy. Ważnym działaniem $\mathrm{w}$ systemie wsparcia jest też powołanie powiatowych ośrodków koordynacyjno-rehabilitacyjno-opiekuńczych, obejmujących wczesnym wspomaganiem rozwoju dzieci w wieku 0-7 lat i osoby z niepełnosprawnością. Zadaniem tego rozwiązania jest wzmocnienie istniejących form pomocy i skoordynowanie działalności różnych placówek funkcjonujących w powiecie.

Wypracowanie spójnych uregulowań prawnych gwarantujących udzielenie adekwatnego wsparcia małym dzieciom i uczniom posiadającym orzeczenie o potrzebie kształcenia specjalnego $\mathrm{z}$ powodu niepełnosprawności oraz osobom dorosłym, przez współpracujące ze sobą systemy: oświaty, zdrowia i polityki społecznej, powinno być także celem działania środowisk zajmujących się teorią i praktyką pedagogiczną. Podejście takie może przyczynić się do zauważania i zapewniania przez władze samorządowe, potrzeb wszystkich mieszkańców, bez ignorowania jakiejkolwiek z grup i do tworzenia warunków sprzyjających wyrównywaniu szans osób z niepełnosprawnością. $W$ tym kontekście ważnym zadaniem społecznym jest również umożliwienie osobom z orzeczeniem o niepełnosprawności 
lub stopniu niepełnosprawności ${ }^{4}$ oraz $\mathrm{z}$ orzeczeniem o potrzebie kształcenia specjalnego ${ }^{5}$ stanowienia o swoim życiu lub/i upoważnienia innej osoby do pomocy w rozwiązywaniu problemów.

Między innymi taki również był cel działań podejmowanych przez organizacje pozarządowe zrzeszone $\mathrm{w}$ Warszawskim Forum Inicjatyw na Rzecz Osób z Niepełnosprawnością Intelektualną (WFIRONI), które postulowały do Biura Projektów i Pomocy Społecznej o kontynuowanie działań prowadzonych w systemie oświaty wobec uczniów z niepełnosprawnością i wspieranie absolwentów szkół $\mathrm{w}$ rozwiązywaniu problemów życia dorosłego. Inicjatywy podejmowane przez organizacje społeczne znalazły uznanie pracowników urzędu i w 2016 r. Biuro Projektów i Pomocy Społecznej Urzędu m.st. Warszawy ogłosiło konkurs dla organizacji pozarządowych na realizację zadania społecznego, którego kontekst wynikał z Priorytetu I. Warszawskiego Programu Działań na Rzecz Osób Niepełnosprawnych na lata 2010-2020. Tematem konkursu było:

${ }^{4}$ Instytucją orzekającą o niepełnosprawności lub stopniu niepełnosprawności jest powiatowy zespół do spraw orzekania działający na podstawie ustawy z dnia 27 sierpnia 1997 r. o rehabilitacji zawodowej i społecznej oraz zatrudnianiu osób niepełnosprawnych (tj. Dz.U. z 2016 r., poz. 2046). Uzyskanie tego orzeczenia oznacza prawne potwierdzenie statusu danej osoby jako osoby niepełnosprawnej i umożliwia jej korzystanie ze świadczeń i przywilejów takich jak np. odliczenia podatkowe, zasiłki, ulgowe przejazdy, udział w zajęciach warsztatów terapii zajęciowej, środowiskowym dziennym domu pomocy społecznej bądź całodobowym domu pomocy społecznej. Konkluzja: orzeczenie może być wydane na wniosek osoby zainteresowanej lub jej przedstawiciela ustawowego albo (jeżeli zgodę wyrazi osoba zainteresowana lub jej przedstawiciel) na wniosek ośrodka pomocy społecznej. Na podstawie zaleceń zawartych w orzeczeniu ukierunkowywane są działania związane z prowadzoną terapią i rehabilitacją osoby z niepełnosprawnością.

${ }^{5}$ Orzeczenie o potrzebie kształcenia specjalnego wydają zespoły orzekające działające $w$ publicznych poradniach psychologiczno-pedagogicznych. Orzeczenie służy celom edukacyjnym i określa potrzeby: specjalną organizację procesu dydaktyczno-wychowawczego, dostosowania programu i metod dydaktycznych i zaleca niezbędne zajęcia rewalidacyjne do potrzeb dzieci i młodzieży z niepełnosprawnością sensoryczną bądź intelektualną albo resocjalizacyjne dla niedostosowanych społecznie i socjoterapeutyczne dla zagrożonych niedostosowaniem społecznym w stosownym dokumencie. 
Wykorzystywanie systemu informacji na rzecz poprawy jakości życia osób z niepełnosprawnościami i ich rodzin. Niniejszy artykuł przedstawia zadania realizowane przez organizację społeczną, która wygrała konkurs i podjęła próbę wspierania dorosłych osób $\mathrm{z}$ niepełnosprawnością i udzielanie im pomocy $\mathrm{w}$ rozwiązywaniu problemów prawnych, organizacyjnych i z zakresu rehabilitacji społecznej i zawodowej.

\section{Utworzenie punktu Informacyjno-Koordynacyjnego dla Osób z Niepełnosprawnością (PIKON)}

Pierwotny projekt punktu Informacyjno-Koordynacyjnego dla Osób z Niepełnosprawnością opracowany przez WFIRONI dotyczył wyłącznie zaspokajania potrzeb absolwentów kończących proces edukacji w szkołach zawodowych, w tym specjalnych, w trzyletnich szkołach przysposabiających do pracy dla uczniów z niepełnosprawnością intelektualną $\mathrm{w}$ stopniu umiarkowanym lub znacznym oraz osób z niepełnosprawnością intelektualną w stopniu głębokim kończących udział $\mathrm{w}$ zajęciach rewalidacyjno-wychowawczych. $\mathrm{W}$ związku z innym zakresem wymagań konkursowych pierwszy projekt działań został zmodyfikowany tak, by PIKON obejmował wsparciem konsultacyjno-informacyjnym wszystkie grupy osób z niepełnosprawnością zamieszkałe na terenie m.st. Warszawy, ich rodziny i/lub opiekunów prawnych oraz, by do udzielania konsultacji, porad i pomocy w rozwiązywaniu problemów byli włączani przedstawiciele podmiotów publicznych i niepublicznych działających $\mathrm{w}$ ramach polityki społecznej. Dzięki informacjom przekazywanym przez PIKON, podmioty te mają możliwość uaktualniania i weryfikowania potrzeb zgłaszanych przez interesariuszy, niezbędnych do zapewniania potrzeb osób $\mathrm{z}$ niepełnosprawnością. Głównymi celami przyjętymi do realizacji przez PIKON są:

1) upowszechnienie oferty miasta dotyczącej aktywizacji społecznej i zawodowej osób z niepełnosprawnością i ich rodzin/ /opiekunów poprzez dostępność do pełnej informacji o insty- 
tucjach społecznych i organizacjach pozarządowych udzielających wsparcia,

2) rozpoznanie dostępnych $w$ mieście zasobów materialnych (instytucji publicznych i prowadzonych przez organizacje NGO) i legislacyjnych, umożliwiających aktywizację społeczną i zawodową osób z niepełnosprawnością oraz ich rodzin/opiekunów,

3) przekazywanie przez PIKON w formie sprawozdań cząstkowych, informacji zbiorczej do Biura Projektów i Pomocy Społecznej Urzędu m.st. Warszawy oraz opracowanie raportu na zakończenie pilotażu,

4) konsolidowanie współpracy i komunikacji między podmiotami samorządowymi, rządowymi i pozarządowymi działającymi w obszarze polityki społecznej na terenie miasta.

Decyzją komisji konkursowej pilotażowe prowadzenie działań informacyjno-koordynacyjnych w okresie od 1 lipca 2016 do 30 listopada 2018 r. przyznano Fundacji Pomocy Ludziom Niepełnosprawnym. Koordynatorem Projektu z ramienia fundacji została Dorota Koman, funkcję kierownika biura PIKON powierzono Barbarze Szostak, odpowiedzi na pytania udzielają eksperci: Iwona Grzesińska, Lidia Klaro-Celej, Zofia Pągowska, Teresa Serafin, Anna Witarzewska.

Osoby zainteresowane rozwiązaniem swoich problemów przy pomocy PIKON mają możliwość korzystania ze strony internetowej: www.pikon.um.warszawa.pl. Są na niej zamieszczane odpowiedzi na pytania zadawane przez interesariuszy drogą e-mailową lub w trakcie wizyty w PIKON-ie. Odpowiedzi udzielają eksperci. Na stronie podano także adres e-mail: kontakt@pikon.org.pl.

\section{Sposób zbierania danych i realizowanie przyjętych celów przez PIKON}

Realizację zadań punktu Informacyjno-Koordynacyjnego dla Osób z Niepełnosprawnością prowadzi biuro PIKON we współpracy z ekspertami. 
Aby przyjęte cele były osiągnięte, zaprojektowano model gromadzenia danych, w bazie informatycznej ${ }^{6} \mathrm{i}$ ich przechowywania, w układzie: a) zbiór podmiotów samorządowych i pozarządowych, b) adres e-mail i kontakt telefoniczny każdego z nich, c) charakterystyka prowadzonej działalności mającej wpływ na rozwiązywanie problemów, istotnych z punktu widzenia użytkownika, w układzie: typ instytucji, siedziba, dokładny adres, dzielnica, instytucja nadrzędna, dane kontaktowe, obszar, rodzaj aktywności skierowanej do osób z niepełnosprawnością, dodatkowe dane identyfikujące grupy docelowe objęte działaniem danego podmiotu.

W celu nawiązania współpracy z instytucjami polityki społecznej i organizacjami NGO zostały wysłane (pocztą elektroniczną) do 300 podmiotów, informacje o PIKON-ie wraz z zaproszeniem do współpracy. Na tej podstawie eksperci PIKON-u opracowali katalog instytucji i podmiotów udzielających wsparcia osobom z niepełnosprawnością i realizujących konkretne zadania problemowe (rehabilitację społeczną w Warsztatach Terapii Zajęciowej, Środowiskowym Domu Samopomocy itp.). Założono, że na wzrost rozpoznania dostępnych $\mathrm{w}$ mieście zasobów materialnych, podniesienie współpracy pomiędzy podmiotami samorządowymi i pozarządowymi oraz na aktywność społeczną i zawodową osób z niepełnosprawnością, może mieć wpływ informacja przekazywana zainteresowanym przez pracowników biura PIKON.

Działania wspierające osoby $z$ niepełnosprawnością i/lub ich rodziny w rozwiązywaniu problemów są wczytywane do bazy danych według: wieku, płci, zgłaszanych problemów, sposobu interwencji, rodzaju udzielonej informacji i/lub najlepszej metody rozwiązania przedstawionej sprawy ${ }^{7}$. Dzięki temu osoby te swobodnie i otwarcie opowiadają o swoich problemach. Rodzaj porad i informacji oraz sposób konsultacji objęty jest stałym trybem dokumentowania.

${ }^{6}$ Projekt bazy danych w systemie MS Access 2016 opracowała informatyk Anna Pogorzelec.

7 Dane są wczytywane z zachowaniem anonimowości interesariuszy. 
Na podstawie problemów zgłaszanych przez osoby z niepełnosprawnością i gromadzonych w czasie rocznej działalności PIKON-u w bazie danych, powstała możliwość określenia potrzeb, z jakimi najczęściej borykają się osoby odwiedzające biuro i/lub zadające pytania, telefonicznie bądź e-mailem. Kategorie zidentyfikowanych potrzeb zostały przedstawione $\mathrm{w}$ tabeli poniżej.

Tabela 1. Kategorie potrzeb osób zgłaszanych w okresie od lipca 2017 r. do 7 listopada 2017 r. przez zainteresowanych, na podstawie bazy danych PIKON-u

\begin{tabular}{|c|c|}
\hline Określenie kategorii potrzeb & Szczegółowe problemy oznaczone podpunktami \\
\hline 1. Brak informacji i wiedzy o: & $\begin{array}{l}\text { 1.1. uprawnieniach osób z niepełnosprawnością wy- } \\
\text { nikających z regulacji prawnych lub lekceważą- } \\
\text { ce podejście odpowiedzialnych instytucji do po- } \\
\text { trzeb tych osób, } \\
\text { 1.2. formach wsparcia, rehabilitacji przysługującej } \\
\text { osobom z niepełnosprawnością, } \\
\text { 1.3. innych formach wsparcia, np. dotyczących sys- } \\
\text { temu edukacji, wczesnego wspomagania rozwo- } \\
\text { ju małych dzieci, } \\
\text { 1.4. zadaniach PIKON i złożenie wizyty z ciekawości }\end{array}$ \\
\hline $\begin{array}{l}\text { 2. Brak pracy, brak pomocy w po- } \\
\text { szukiwaniu pracy }\end{array}$ & $\begin{array}{l}\text { 2.1. brak szkoleń dostosowanych do potrzeb osób } \\
\text { z niepełnosprawnością, } \\
\text { 2.2. odrzucenie przez pracodawcę osoby z niepełno- } \\
\text { sprawnością jako pracownika, mobing, } \\
\text { 2.3. poszukiwanie pracy zgodnej z uzyskanymi kwa- } \\
\text { lifikacjami }\end{array}$ \\
\hline 3. Brak pomocy w: & $\begin{array}{l}\text { 3.1. codziennym funkcjonowaniu, zakupach, } \\
\text { 3.2. społecznym funkcjonowaniu, np. przez tworze- } \\
\text { nie kręgu wsparcia, } \\
\text { 3.3. merytorycznym wsparciu w rozwiązywaniu } \\
\text { problemów bieżących, } \\
\text { 3.4. zabezpieczeniu socjalne osoby z niepełnospraw- } \\
\text { nością po ukończeniu 25. roku życia przez insty- } \\
\text { tucje pomocowe }\end{array}$ \\
\hline $\begin{array}{l}\text { 4. Przystosowanie najbliższego } \\
\text { otoczenia (budynek), (miesz- } \\
\text { kanie) }\end{array}$ & $\begin{array}{l}\text { 4.1. brak wiedzy o możliwości uzyskania pomocy } \\
\text { w dostosowaniu mieszkania i/lub budynku } \\
\text { (winda, szerokie wejście) lub lekceważące po- } \\
\text { dejście odpowiedzialnych instytucji do zapew- } \\
\text { nienia tych uprawnień, }\end{array}$ \\
\hline
\end{tabular}


cd. tab. 1

\begin{tabular}{|c|c|}
\hline Określenie kategorii potrzeb & Szczegółowe problemy oznaczone podpunktami \\
\hline & $\begin{array}{l}\text { 4.2. brak pomocy merytorycznej w załatwieniu prob- } \\
\text { lemów wspólnoty mieszkaniowej i innych pod- } \\
\text { miotów zajmujących się mieszkalnictwem, } \\
\text { 4.3. nieusuwanie barier architektonicznych przez } \\
\text { PFRON, nieoznakowanie miejsc parkingowych } \\
\text { dla osób z niepełnosprawnością }\end{array}$ \\
\hline $\begin{array}{l}\text { 5. Usługi i zaopatrzenie w sprzęt, } \\
\text { do osobistego używania: }\end{array}$ & $\begin{array}{l}\text { 5.1. sprzęt rehabilitacyjny, protezy, } \\
\text { 5.2. usługi rehabilitacyjne mające na celu poprawę } \\
\text { i utrzymanie stanu zdrowia }\end{array}$ \\
\hline 6. Transport: & $\begin{array}{l}\text { 6.1. zapewnienie stałego transportu na rehabilitację, } \\
\text { leczenie, } \\
\text { 6.2. zapewnienie transportu w przypadkach nagłych, } \\
\text { okazjonalnym }\end{array}$ \\
\hline $\begin{array}{l}\text { 7. Brak dostępu do specjalistów } \\
\text { lekarzy: }\end{array}$ & $\begin{array}{l}\text { 7.1. wyznaczanie odległych terminów wizyt, } \\
\text { 7.2. odmowa przyjęcia, utrudniony dostęp do nie- } \\
\text { których specjalistów (ginekolog, stomatolog), szpi- } \\
\text { tali (tylko z rodzicem) }\end{array}$ \\
\hline 8. Trudności finansowe: & $\begin{array}{l}\text { 8.1. brak środków na „życie”, leki, } \\
\text { 8.2. brak środków finansowych na rehabilitację }\end{array}$ \\
\hline 9. Braki, luki w orzeczeniach: & $\begin{array}{l}\text { 9.1. terminy odwoławcze jako ograniczenie, } \\
\text { 9.2. braki w zaleceniach dotyczących rehabilitacji spo- } \\
\text { łecznej (np. warsztaty terapii zajęciowej), } \\
\text { 9.3. ponowienie orzeczenia, zmiana orzeczenia (np. } \\
\text { zmiana kwalifikacji niepełnosprawności) }\end{array}$ \\
\hline $\begin{array}{l}\text { 10. Niedostateczna realizacja } \\
\text { uprawnień osób z niepełno- } \\
\text { sprawnością przez odpo- } \\
\text { wiednie instytucje: }\end{array}$ & $\begin{array}{l}\text { 10.1. nieprzestrzeganie przepisów odnoszących się } \\
\text { do zapewniania realizacji potrzeb osób z nie- } \\
\text { pełnosprawnością, } \\
\text { 10.2. złe, zdaniem zainteresowanych, decyzje orze- } \\
\text { cznicze - brak "zabezpieczeń" dla osób z nie- } \\
\text { pełnosprawnością, } \\
\text { 10.3. luki w prawie, zła wola instytucji }\end{array}$ \\
\hline $\begin{array}{l}\text { 11. Brak rozwiązań, narzędzi } \\
\text { wsparcia: }\end{array}$ & $\begin{array}{l}\text { 11.1. odnoszących się do funkcjonowania osób z nie- } \\
\text { pełnosprawnością w stopniu znacznym po } \\
\text { śmierci opiekunów, } \\
\text { 11.2. ustalenia stałej, obowiązkowej metodyki pracy } \\
\text { z uczniem z niepełnosprawnością }\end{array}$ \\
\hline
\end{tabular}

Źródło: opracowanie własne, na podstawie bazy danych PIKON 
Dla potrzeb analizy danych i przejrzystości jej wyników dokonano także kategoryzacji przyczyn i rodzajów niepełnosprawności i zapisywano ją zgodnie $\mathrm{z}$ kodami stosowanymi w orzecznictwie ${ }^{8}$. Przyjęto następujące kategorie niepełnosprawności:

1) intelektualna, zdefiniowana kodami 01-U, 12-C,

2) sensoryczna (wzrok), zdefiniowana kodami 04-O,

3) sensoryczna (słuch), zdefiniowana kodami O3-L,

4) ruchowa, zdefiniowana kodami 05-R,

5) psychiczna, zaburzenia na poziomie ośrodkowego układu nerwowego zdefiniowana kodami 02-P, O6E,

6) niepełnosprawność związana $z$ wydarzeniem losowym (wypadek, choroba do 55. roku życia), zdefiniowana kodami 08-T, 09-M, 11-I, 09-M,

7) niepełnosprawność związana $\mathrm{z}$ utratą zdrowia w związku $\mathrm{z}$ wiekiem powyżej 55. roku życia zdefiniowana kodami 10-N, 07-S.

\section{Charakterystyka osób zgłaszających się do PIKON-u}

W okresie od lipca 2017 r. do 7 listopada 2017 r. z pomocy PIKON skorzystało 409 osób (100\%). W tej grupie najwięcej osób miało więcej niż 50 lat. Oznacza to, że wymieniona grupa osób nie posiada wiedzy o przysługujących im formach wsparcia i rehabilitacji, nie uzyskuje pomocy w załatwieniu problemów życiowych, napotyka na bariery mentalne i architektoniczne. Graficzny obraz grup wiekowych Interesariuszy PIKON przedstawia wykres nr 1.

Najliczniejszą grupę zgłaszającą się do PIKON-u stanowiły kobiety - $221(\sim 54 \%), 180$ osób ( 44\%) stanowili mężczyźni, a 8 osób ( 2\%), spośród zadających pytania drogą email, nie podało swojej płci. Poniżej wykres 2. pokazuje podział interesariuszy według płci.

8 Rozporządzenie Ministra Gospodarki, Pracy i Polityki Społecznej z 15 lipca 2003 r. w sprawie orzekania o niepełnosprawności i stopniu niepełnosprawności (Dz.U. z 2015 r., poz. 110). 


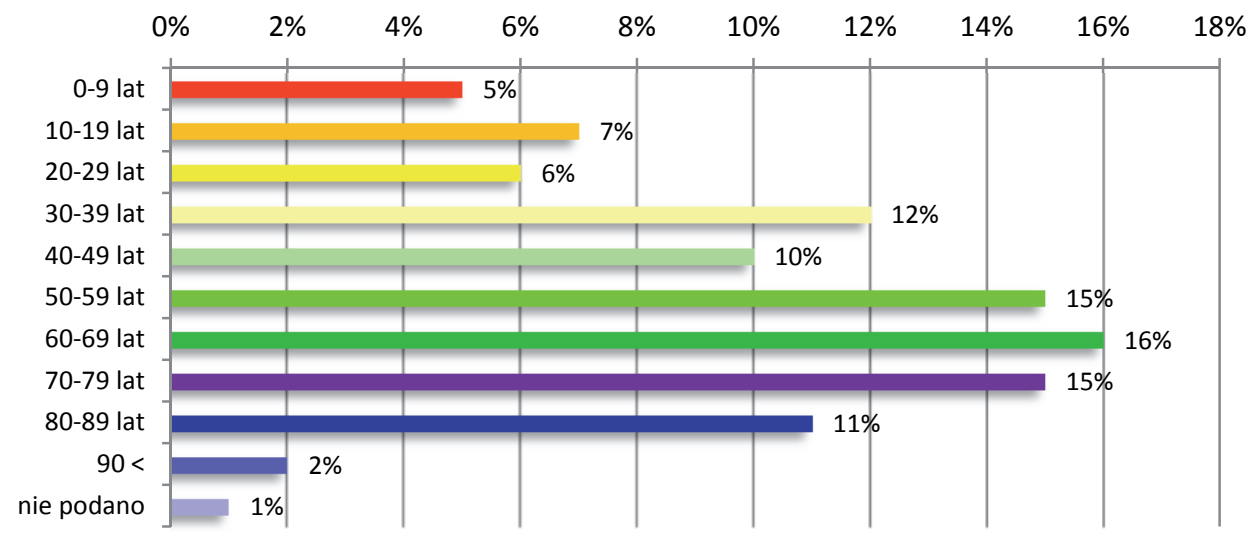

Wykres 1. Osoby zgłaszające się do biura PIKON-u z prośbą o pomoc w rozwiązaniu problemów, według grup wiekowych.

Źródło: opracowane własne na podstawie bazy danych PIKON

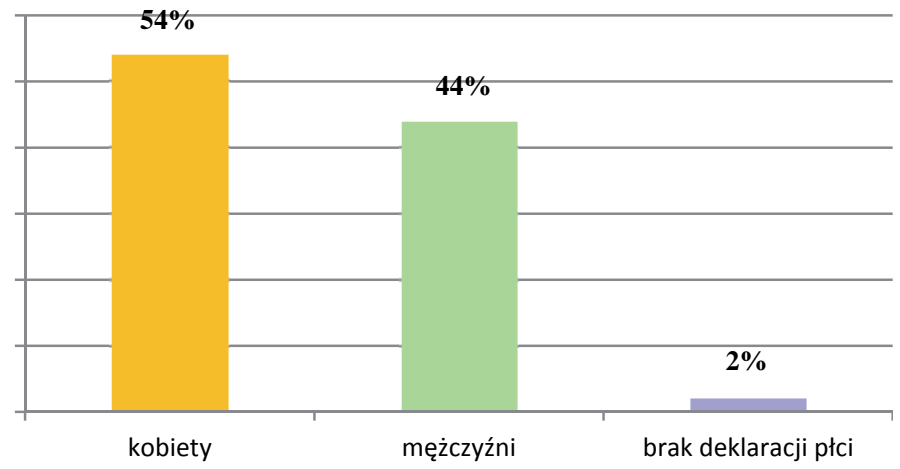

Wykres 2. Podział interesariuszy według płci.

Źródło: opracowanie na podstawie bazy danych PIKON

Najliczniejsza grupa osób (139) posiada orzeczenia powiatowego zespołu do spraw orzekania z powodu niepełnosprawności ruchowej Najczęściej podawane rodzaje niepełnosprawności interesariuszy PIKON przedstawia wykres nr 3. 


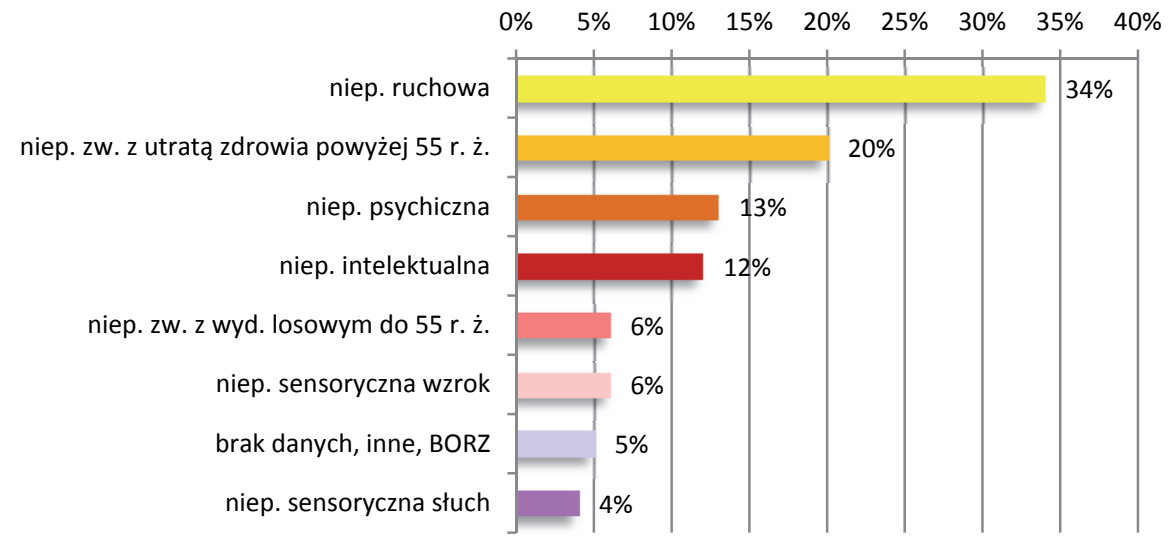

Wykres 3. Rodzaje niepełnosprawności podawane przez Interesariuszy PIKON-u Źródło: opracowano na podstawie bazy danych

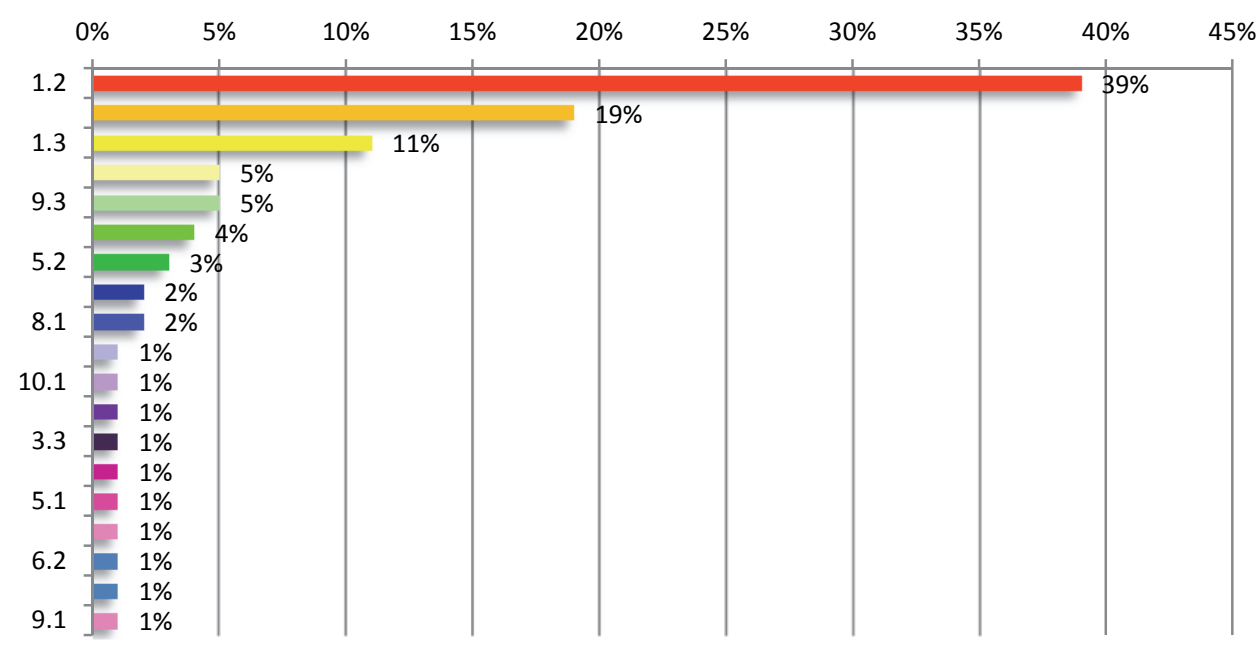

Wykres 4. Problemy wskazywane przez interesariuszy PIKON-u; oś lewa przedstawia kategorie potrzeb.

Źródło: opracowano na podstawie bazy danych PIKON 
Każdy z przedstawionych na wykresie rodzajów niepełnosprawności generuje inny zakres potrzeb. Najczęściej wskazywane przez Zainteresowanych, problemy przedstawia wykres 4., na którym określenia oznaczone cyframi od 1.2-9.1 odnoszą się do kategorii potrzeb osób zidentyfikowanych $\mathrm{w}$ tabeli nr 1 niniejszego opracowania, zgłaszanych w okresie od lipca 2017 r. do 7 listopada 2017 r. przez zainteresowanych.

Z powyższego wykresu wynika, że najczęściej przedstawianymi problemami wskazywanymi przez około 282 (69\%) osoby z niepełnosprawnością były problemy z zakresu kategorii 1.1-1,3. Oznacza to, że zainteresowani nie posiadają wiedzy o wynikających z obowiązujących przepisów prawa, uprawnieniach osób z niepełnosprawnością do korzystania z różnych form wsparcia i rehabilitacji społecznej i zawodowej.

\section{Analiza potrzeb zgłaszanych przez wybrane grupy osób z niepełnosprawnością}

Najliczniejszą grupę interesariuszy PIKON-u stanowią osoby z niepełnosprawnością ruchową (34\% z liczby 409 osób), które zgłaszały problemy przedstawione na wykresie 5 .

Łącznie 71\% osób z niepełnosprawnością ruchową zgłaszało problemy w uzyskaniu wiedzy i informacji o uprawnieniach wynikających $\mathrm{z}$ regulacji prawnych, formach wsparcia i rehabilitacji oraz innych formach wsparcia, w tym o wczesnym wspomaganiu rozwoju dziecka (przedstawionych w odnośniku 9). Wśród problemów zgłaszanych przez 5 osób (1\%) w każdej z kategorii, były problemy: ze znalezieniem stałego transportu na rehabilitację i leczenie (kategoria 6.1), znalezieniem nowej pracy z powodu odrzucenia przez pracodawcę tej osoby jako pracownika (kategoria 2.3), uzyskaniem wsparcia w rozwiązywaniu problemów bieżących (kategoria 3.3), usuwaniem barier architektonicznych i tworzeniem miejsc parkingowych (kategoria 4.3), pokonaniem formalnych błędów w ustaleniach wynikających z orzeczeń, dotyczących rehabilitacji społecznej (kategoria 9.2), 
uzyskaniem nowych orzeczeń lub zmianą w dotychczasowych orzeczeniach (kategoria 9.3) oraz pomocą w negocjacjach $\mathrm{z}$ instytucjami, które nie przestrzegają przepisów odnoszących się do wspierania osób z niepełnosprawnością (kategoria 10.1) zgłaszane były.

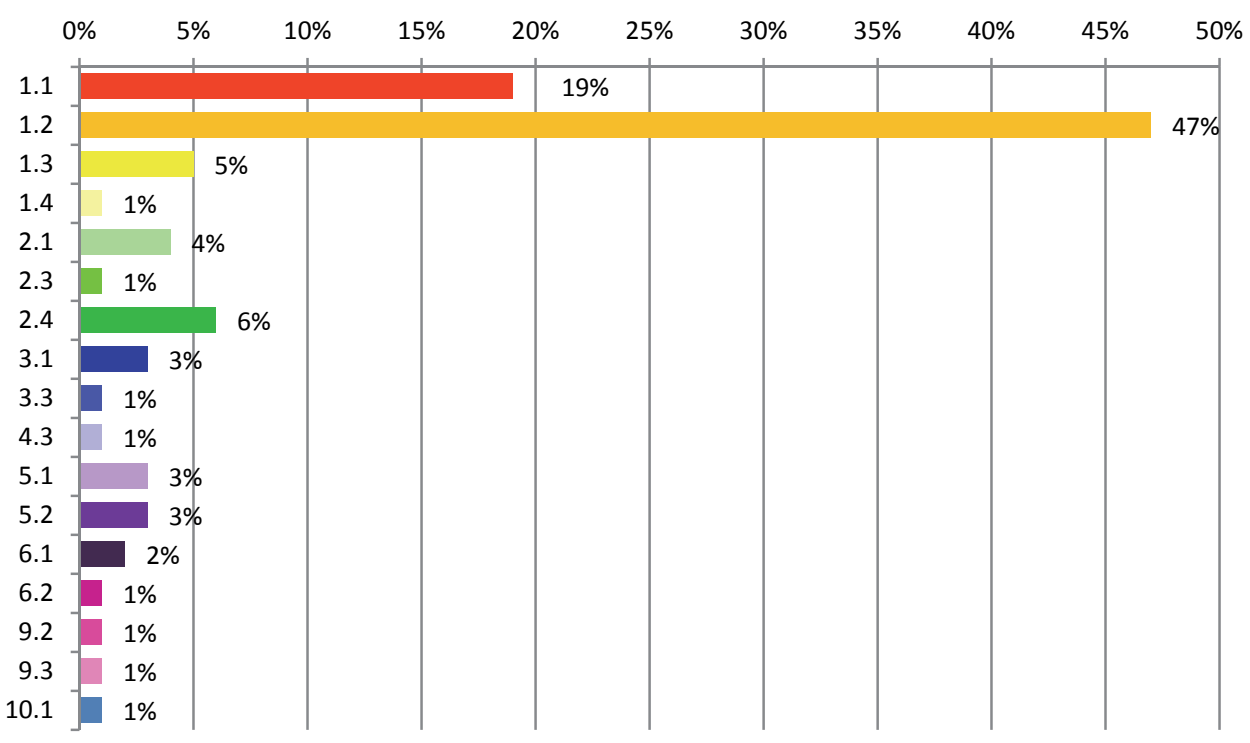

Wykres 5. Potrzeby zgłaszane przez osoby z niepełnosprawnością ruchową Źródło: opracowano na podstawie bazy danych PIKON ${ }^{9}$

${ }^{9}$ Legenda: lewa oś wykresu przedstawia kategorie potrzeb przedstawione $\mathrm{w}$ tabeli 1 . Dla przypomnienia podaje przykład wybranych kategorii potrzeb zgłaszanych przez interesantów wskazanych na osi pionowej:

- kategoria 1.1 - 19\% (78 osób) brak wiedzy o uprawnieniach wynikających $\mathrm{z}$ regulacji prawnych,

- kategoria 1.2 - 47\% (192 osoby) brak informacji i wiedzy na temat form wsparcia i rehabilitacji,

- kategoria 1.3- 6\% (25) osób problemy związane poszukiwaniem form wsparcia w systemie edukacji, wczesnego wspomagania rozwoju małych dzieci,

- kategoria 2.3 - 6\% (25 osób) problemy związane z poszukiwaniem pracy zgodnej z kwalifikacjami. 
Potrzeby wynikające z nieznajomości lub braku wiedzy na temat norm prawnych, przez osoby różnymi niepełnosprawnościami, określone w kategorii 1.1, były zgłaszane przez osoby z różnych grup niepełnosprawności, co ilustruje wykres 6.

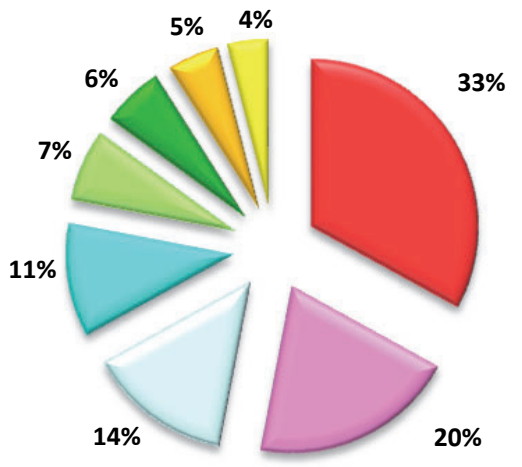

\author{
niep. ruchowa \\ घiep. zw. z utratą zdrowia \\ $\triangle$ niep. intelektualna \\ niep. psychiczna \\ niep. sens. wzrok \\ niep. zw. z wydarzeniem losowym \\ $\square$ brak danych \\ niep.sens. słuch
}

Wykres 6. Rodzaje niepełnosprawności osób zgłaszających potrzeby wynikające z braku wiedzy o przepisach prawa, na podstawie których mogą uzyskać wsparcie społeczne

Źródło: opracowano na podstawie bazy danych PIKON

Przeważająca liczba osób zgłasza potrzebę pomocy w wyjaśnieniu przepisów prawa i wynikających z nich możliwości uzyskania pomocy. Potrzeby takie zgłaszały osoby z: niepełnosprawnością ruchową - 135 osób ( 33\%), niepełnosprawnością związaną z utratą zdrowia powyżej 55. roku życia - około 82 osoby (20\%), niepełnosprawnością intelektualną około 57 osób ( 14\%) oraz niepełno-

- kategoria 2.1 - 4\% (29 osób) brak szkoleń dla osób z niepełnosprawności,

- kategoria 3.1- 3\% (12 osób) brak pomocy w codziennym funkcjonowaniu,

- kategoria 5.1 - 3\% (12 osób) brak pomocy w zaopatrzeniu w sprzęt rehabilitacyjny i protezy,

- kategoria 5.2 - 3\% (12 osób) brak dostępu do rehabilitacyjnych

- kategoria 6.2 - 2\% (8 osób) brak pomocy w uzyskaniu transportu w nagłych sytuacjach życiowych kategoria. 
sprawnością wynikającą z choroby psychicznej - 45 osób ( 11\%). Potrzeby takie zgłaszały również osoby z niepełnosprawnościami sensorycznymi (wzroku i słuchu) - mniej niż 10\%, osoby, które nabawiły się niepełnosprawności w wyniku zdarzenia losowego i 21 osób $(\sim 5 \%)$, które nie ujawniły rodzaju swojej niepełnosprawności podczas telefonicznego zadawania pytań.

Osoby z niepełnosprawnością intelektualną najczęściej zgłaszały następujące problemy:

- brak wiedzy o przysługujących im formach wsparcia i rehabilitacji,

- brak informacji o uprawnieniach do korzystania rehabilitacji społecznej i różnych form wsparcia oraz problemy ze zrozumieniem zaleceń zawartych $\mathrm{w}$ orzeczeniach i/lub potrzebę zmiany lub wydania nowego dokumentu stwierdzającego niepełnosprawność. Rzadziej wskazywano na: brak pomocy w zabezpieczeniu socjalnym osób do 25. roku życia, potrzebę zaopatrzenia w sprzęt rehabilitacyjny, utrudnienia we współpracy $\mathrm{z}$ instytucjami wynikające $\mathrm{z}$ niespójności przepisów prawa albo złej woli pracowników instytucji, z uzyskaniem stałego transportu na rehabilitację/leczenie oraz brak środków finansowych na „życie”, zakup leków.

Analiza kategorii potrzeb pokazuje, że brak wiedzy o możliwych uprawnieniach określonych w regulacjach prawnych zgłasza $74 \%$ osób z niepełnosprawnością intelektualną, 17\% osób z niepełnosprawnością słuchową i niepełnosprawnością ruchową oraz 33\% osób, które nabyły niepełnosprawność w związku z wydarzeniem losowym, (nie)przestrzeganie przepisów określających zasady wydawania orzeczeń o niepełnosprawności i/lub niechęć do udzielania wsparcia przez pracowników ośrodków pomocy rodzinie zgłasza $74 \%$ osób z niepełnosprawnością intelektualną, nieprzystosowanie najbliższego otoczenia zgłasza $75 \%$ osób z niepełnosprawnością ruchową i $25 \%$ osób z niepełnosprawnością wynikającą z choroby psychicznej. Natomiast brak rozwiązań określonych prawem, zapewniających wspieranie osób, które stały się niepełnosprawnymi po 55. roku życia, zgłosiło $100 \%$ osób. 


\section{Nawiązanie współpracy z instytucjami polityki społecznej}

Do współpracy w udzielaniu wsparcia informacyjno-koordynacyjnego i pomocy w rozwiązywaniu problemów osób zgłaszającym się do PIKON-u zostało zaproszonych 496 podmiotów (100\%) działających w różnych obszarach polityki społecznej, w tym 54\% NGO, $44 \%$ podmiotów publicznych i $2 \%$ - podmioty prywatne. Wśród tych podmiotów:

- $42 \%$ udziela wsparcia osobom z niepełnosprawnością intelektualną,

- 22\% udziela wsparcia osobom $\mathrm{z}$ niepełnosprawnością psychiczną,

- 16\% działa na rzecz osób z niepełnosprawnością wzroku,

- 14 \% działa na rzecz osób z niepełnosprawnością słuchu,

- 6\% wspiera osoby z niepełnosprawnością ruchową.

W jakich obszarach polityki społecznej działają współpracujące z PIKON podmioty przedstawia wykresie 7.

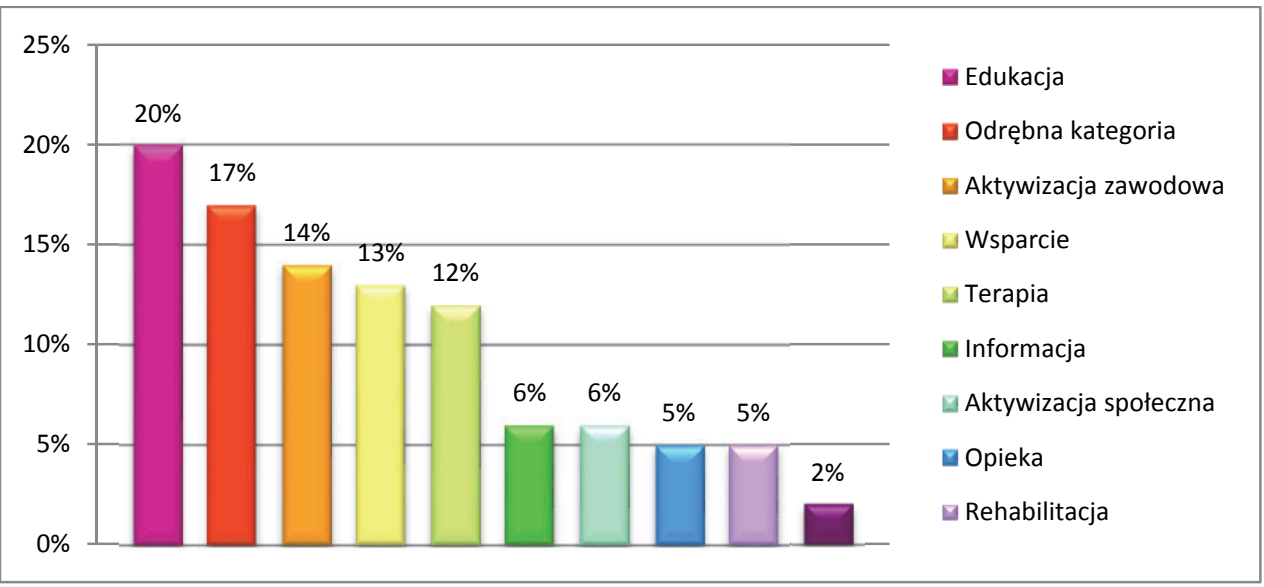

Wykres 7. Obszary działań instytucji współpracujących z PIKON-em w udzielaniu wsparcia osobom z niepełnosprawnością Źródło: opracowano na podstawie bazy danych PIKON 
Powyższy wykres pokazuje, że najtrudniej było PIKON-owi nawiązać współpracę pozwalającą na udzielanie wsparcia osobom $\mathrm{z}$ niepełnosprawnością $\mathrm{z}$ instytucjami działającymi w obszarach: informacja, aktywizacja społeczna, opieka, rehabilitacja i diagnoza. Najłatwiej można było uzyskać wsparcie z podmiotami działającymi w systemie edukacji.

Z serwisu WWW PIKON-u (w omawianym okresie - od lipca 2016 r. do 7 listopada 2017 r.) skorzystało 1135 (100\%) użytkowników z polskojęzycznym systemem operacyjnym, tworząc 1663 sesji i dokonując 5930 odsłon stron.

Nowi użytkownicy stanowili 33,1\% a użytkownicy korzystający ze strony WWW kolejny raz - 66,9 \%. Wśród odwiedzających serwis WWW byli: mieszkańcy Polski (Warszawa, Toruń i Poznań) 1471 sesji $(88,45 \%)$, ale także mieszkańcy USA (Austin) - 69 sesji $(4,15 \%)$ i mieszkańcy Brazylii (Parauapeba) - 58 sesji (3,49\%).

\section{Podsumowanie}

Od wielu lat funkcjonują $\mathrm{w}$ Polsce normy prawne uprawniające do podejmowania decyzji przez władze samorządu terytorialnego w sprawie form działań na rzecz rozwoju społeczności lokalnych. Kompetencje te dotyczą także zapewniania przez gminy, powiaty i województwa, wszystkim mieszkańcom:

- kształcenia dostosowanego do potrzeb oraz zajęć rewalidacyjnych, resocjalizacyjnych i innych terapeutycznych, jak najbliżej miejsca zamieszkania,

- świadczeń opieki zdrowotnej wraz z rehabilitacją leczniczą i społeczną,

- miejsc pracy na otwartym, wspieranym i chronionym rynku zatrudnienia oraz rehabilitacji zawodowej dla osób kończących naukę szkolną,

- likwidacji barier, nie tylko architektonicznych,

- wspomagania rozwoju dzieci/uczniów od wychowania przedszkolnego poprzez nauczanie $\mathrm{w}$ szkole podstawowej i szkole ponadpodstawowej, aż po wspieranie kształcenia wyższego, 
- kontynuowania udzielania świadczeń, w tym udzielania szczegółowych informacji i profesjonalnego wsparcia rodzinom osób z niepełnosprawnością (np. w zakresie pomocy społecznej, świadczeń socjalnych, zapewnienia mieszkalnictwa chronionego i ewentualnie specjalistycznych usług opiekuńczych dzieciom i młodzieży po zakończeniu edukacji szkolnej oraz dorosłym którzy nie są w stanie funkcjonować bez pomocy osoby drugiej).

Przedstawione $\mathrm{w}$ artykule informacje o działalności PIKON-u pokazują, że obowiązujące przepisy prawne nie gwarantują zainteresowania władz ich stosowaniem i nie są wystarczające do uzyskania:

- wiedzy przez osoby z niepełnosprawnością o możliwych formach pomocy, szczególnie, że są one zawarte w różnych ustawach i rozporządzeniach,

- informacji na temat instytucji udzielających osobom z niepełnosprawnością wsparcia w rozwiązaniu problemów życiowych,

- pomocy z załatwieniu przejazdu, przyjęcia do lekarza, zatrudnienia,

- informacji o instytucjach rehabilitacji społecznej i innych.

Działalność punktu Informacyjno-Koordynacyjnego dla Osób z Niepełnosprawnością (PIKON) pokazuje, że wsparcie informacyjne i koordynowanie działań zmierzających do rozwiązania problemów osób je zgłaszających, może poprawić ich jakość życia.

Już po tym krótkim okresie funkcjonowania PIKON (od lipca 2017 r. do 7 listopada 2017 r.) daje się zauważyć, że wyodrębniono 11 kategorii potrzeb (tabela $\mathrm{nr} 1$ tego opracowania), negatywnie rzutujących na życie dorosłych osób z niepełnosprawnością. Również podmioty współpracujące z PIKON-em, zainteresowane udzielaniem wsparcia wybranym grupom osób z niepełnosprawnością, wskazują na te potrzeby. Na tej podstawie należy wnioskować, iż działania te należy rozwijać i kontynuować. Zainteresowanie stroną internetową PIKON-u przez mieszkańców USA i Brazylii pokazuje, że także oni mogą mieć problemy z uzyskaniem wsparcia w roz- 
wiązaniu problemów życiowych i poszukują podpowiedzi na temat inicjatyw podejmowanych w innych krajach.

Po zakończeniu realizacji tego programu zostanie opracowany szczegółowy raport omawiający zarówno ustalenia dotyczące ewentualnych modyfikacji norm prawnych, jak i rekomendacje do obowiązkowego wspierania dorosłych osób $\mathrm{z}$ niepełnosprawnością przez wszystkie podmioty działające w ramach polityki społecznej.

\section{Literatura}

Karta Praw Osób Niepełnosprawnych uchwalona przez Sejm 1 sierpnia 1997 r.

Kołaczek B., Polityka spoteczna wobec osób niepetnosprawnych, Instytut Pracy i Spraw Socjalnych, Warszawa 2010.

Konwencja o prawach osób Niepełnosprawnych (Dz.U. 2012, poz. 1169)

Normalizacja środowisk życia osób niepetnosprawnych, red. Cz. Kosakowski, A. Krauze, UW-M, Olsztyn 2005.

Rozporządzenie Ministra Gospodarki, Pracy i Polityki Społecznej z 15 lipca 2003 r. $\mathrm{w}$ sprawie orzekania o niepełnosprawności i stopniu niepełnosprawności (Dz.U. z 2015 r., poz. 110).

Ustawa z dnia 14 grudnia 2016 r. Prawo oświatowe (Dz.U. z 2017 r. poz. 59).

Ustawa z dnia 15 czerwca 2012 r. o ratyfikacji Konwencji o prawach osób niepełnosprawnych, sporządzonej w Nowym Jorku dnia 13 grudnia 2006 r. (Dz.U., poz. 882).

Ustawa z dnia 20 czerwca 1992 r. o uprawnieniach do ulgowych przejazdów środkami publicznego transportu zbiorowego (tj. Dz.U. z 2012 r., poz. 1138, z późn. zm.). ustawa z dnia 20 czerwca 1997 r. Prawo o ruchu drogowym (Dz.U. z 2012 r., poz. 1137, z późn. zm.).

Ustawa z dnia 27 sierpnia $1997 \mathrm{r}$. o rehabilitacji zawodowej i społecznej oraz zatrudnianiu osób niepełnosprawnych (tj. Dz.U. z 2016 r., poz. 2046).

Ustawa z dnia 4 listopada 2016 r. o wsparciu kobiet w ciąży i rodzin "Za życiem” (Dz.U., poz. 1860).

Ustawa z dnia 7 września 1991 r. o systemie oświaty (tj. Dz.U. z 2017 r., poz. 2198)

Pedagogika specjalna - kontynuacja tradycji dla przyszłości, red. K.J. Zabłocki, D. Gorajewska, APS, Warszawa 2004.

Zasób danych gromadzonych w bazie informacji PIKON. 